\title{
PENENTUAN KOMPOSISI MEDIA TANAM TERBAIK UNTUK BUDIDAYA SELADA MERAH MENGGUNKANA SISTEM AUTPOT MODIFIKASI
}

\author{
Sophia Dwiratna ${ }^{*}$, Dita Komalasari \\ Departemen Teknik Pertanian dan Biosistem, Fakultas Teknologi Industri Pertanian Universitas \\ Padjadjaran. Jl. Raya Bandung-Sumedang km 21 Jatinangor 43563 \\ *Corresponding author : sophia.dwiratna@unpad.ac.id
}

\begin{abstract}
Autopot an irrigation device which is operated automatically and is capable of providing nutrition in plants without the need for electrical energy. The system is operated via a smart valve that is used to open and close automatically irrigation water by the water conditions in the network system, especially the water level in the network. Basic water level is used as a mechanical sensor for opening and closing the valve automatically without the aid of another power. With these advantages, autopot able to provide water and energy efficiency is very high on a commercial scale hydroponic cultivation. It's just that the system requires very high investment and must be imported. Therefore, this study was conducted to modify Autopot use of materials and simple equipment and test its performance on the cultivation of red lettuce. Autopot modifications performed on tools, growing media and fertigation systems are smart valve replacement valve using a hole in the bottle that works with pressure and gravity. This study aims to determine the performance test autopot modification results in the cultivation of red lettuce as well as to determine the ratio of planting media best on autpot system modifications. Research carried out for 90 days in a greenhouse using descriptive methods. The results showed Autopot Modifications have an average efficiency of the provision of water by $75.86 \%$ - 88.05\% and an average efficiency of water use by $51.43 \mathrm{~kg} / \mathrm{m} 3$ $88.72 \mathrm{~kg} / \mathrm{m}^{3}$, this efficiency is high because of high dihasikan crop production with the use of water low. Planting media between rice husk and humus in the ratio of 50:50 compositions show results better plant growth compared with other growing media composition. plants with irrigation efficiency levels are very high as well minus the electric energy consumption.
\end{abstract}

Keywords: Autopot Modification, Growing Media, Hydrophonic, Fertigation

\begin{abstract}
ABSTRAK
Autopot merupakan perangkat irigasi yang dioperasikan secara otomatis dan mampu pemberian nutrisi pada tanaman tanpa membutuhkan energi listrik. Sistem ini dioperasikan melalui katup pintar yang digunakan untuk membuka dan menutup air irigasi secara otomatis berdasarkan kondisi air di sistem jaringan, terutama ketinggian air dalam jaringan. Dasar ketinggian air digunakan sebagai sensor mekanik untuk menutup dan membuka katub secara otomatis tanpa bantuan tenaga lain. Dengan kelebihan tersebut, autopot mampu memberikan efisiensi air dan energi yang sangat tinggi pada budidaya hidroponik skala komersial. Hanya saja sistem ini membutuhkan investasi yang sangat tinggi dan harus impor. Pada penelitian ini dilakukan modifikasi dan uji kinerja sistem Autopot menggunakan bahan dan peralatan sederhana. Modifikasi Autopot dilakukan pada alat, media tanam dan sistem fertigasi yaitu mengganti katup smart valve menggunakan lubang pada botol yang bekerja dengan tekanan dan gravitasi. Penelitian ini bertujuan untuk mengetahui uji
\end{abstract}


kinerja autopot hasil modifikasi pada budidaya selada merah serta untuk menentukan rasio campuran media tanam yang terbaik pada sistem autpot modifikasi. Penelitian dilaksanakan selama 90 hari di rumah kaca dengan menggunakan metode deskriptif. Hasil penelitian menunjukkan Autopot Modifikasi memiliki efisiensi rata-rata pemberian air sebesar $75.86 \%$ - $88.05 \%$ dan efisiensi rata-rata penggunaan air sebesar $51.43 \mathrm{~kg} / \mathrm{m} 3-88.72 \mathrm{~kg} / \mathrm{m} 3$, efisiensi ini tergolong tinggi karena produksi tanaman yang dihasikan tinggi dengan penggunaan air yang rendah. Campuran media tanam antara arang sekam dan humus dengan rasio komposisi 50:50 menunjukkan hasil pertumbuhan tanaman yang lebih baik dibandingkan dengan komposisi media tanam lain.

Kata kunci: Autopot Modifikasi, Hidroponik, Media Tanam, Fertigasi

\section{PENDAHULUAN}

Tanaman selada sudah dikenal baik oleh masyarakat Indonesia. Masyarakat yang mengkonsumsi sayuran selada akhir-akhir ini menunjukkan peningkatan karena sayuran ini mudah ditemukan di pasar.Selada merupakan sayuran yang mempunyai nilai komersial dan prospek yang cukup baik.Ditinjau dari aspek klimatologis, aspek teknis, ekonomis dan bisnis, selada layak diusahakan untuk memenuhi permintaan konsumen yang cukup tinggi dan peluang pasar internasional yang cukup besar (Haryanto, 2003).Selada juga merupakan salah satu jenis sayuran yang paling sering digunakan sebagai salad di dunia (Junior, 2005).Selada juga merupakan tanaman yang banyak ditanam secara komersial di rumah kaca dan di luar ruangan (Junior, 2005).

Salah satu cara membudidayakan selada adalah dengan menggunakan sistem Autopot, berupa sistem irigasi yang berasal dari Australia yang secara otomatis memberikan kebutuhan air pada tanaman. Nurpilihan, et.al. (2017) menyatakan bahwa sistem Autopot ini mempunyai beberapa kelebihan yaitu, larutan nutrisi yang masuk menuju reservoir dikontrol dengan menggunakan katup yang dikenal dengan sebutan smart valve. Melalui katup ini, larutan nutrisi yang akan masuk ke dalam baki dikontrol dengan cara menyalurkan air hingga mencapai batas maksimal dan menyalurkan kembali nutrisi ketika nutrisi pada baki sudah mencapai batas minimal sehingga penggunaan larutan nutrisi lebih efisien.

$$
\text { Pada Autopot ini juga tidak }
$$
mempergunakan energi listrik atau pompa untuk mengaplikasikannya. Sistem Autopot yang telah dikembangkan di Australia ini pada pengaplikasiannya membutuhkan investasi awal untuk pengadaan alat sehingga pada penelitian ini dibuat sistem Autopot Modifikasi dengan menggunakan bahan lokal untuk menyiasatinya.

Pada penelitian ini akan dilakukan modifikasi pada sistem Autopot yang ada yaitu membuat Autopot dengan memanfaatkan alat dan bahan yang sederhana dan mudah didapatkan di lingkungan sekitar yang berbeda dengan sistem Autopot yang dikembangkan di Australia sehingga penggunaan alat sederhana dapat dijadikan sebagai bagian dari modifikasi sistem Autopot.

Modifikasi Autopot dilakukan pada bagian kontrol pemberian air dari sistem Autopot. Pada Autopot, irigasi dan pemupukan dikontrol dengan menggunakan katup smart valve sedangkan pada Autopot Modifikasi fertigasi dikontrol dengan menggunakan lubang pada botol yang bekerja dengan tekanan dan gravitasi.

Pada Autopot, media yang digunakan yaitu perlite dan vermikulit dengan rasio yang direkomendasikan sebesar 50:50, sedangkan pada Autopot Modifikasi media tanam yang digunakan yaitu media tanam arang sekam dan humus yang akan diuji pada sebelas campuran yang berbeda untuk mengetahui rasio 
campuran media tanam yang terbaik pada pada sistem Autopot Modifikasi. Pemilihan media tanam ini didasarkan pada kemudahan dalam mendapatkan arang sekam dan humus itu sendiri dan harganya yang relatif murah dibandingkan dengan media tanam lain.

Adapun tujuan dari dilakukannya penelitian ini adalah sebagai berikut ;

a. Mengetahui rasio campuran media tanam yang terbaik pada sistem Autopot Modifikasi untuk budidaya tanaman selada merah.

b. Mengetahui pertumbuhan tanaman selada merah pada Autopot Modifikasi dengan melakukan perhitungan keseragaman pertumbuhan;

c. Mengetahui nilai efisiensi penggunaan dan pemberian air pada sistem fertigasi Autopot Modifikasi dan

\section{BAHAN DAN METODE}

Penelitian ini dilaksanakan pada bulan Januari 2016-Maret 2016 selama 90 hari yang berlokasi di Rumah Kaca Fakultas Pertanian, Universitas Padjadjaran, Jatinangor Metode yang digunakan pada penelitian ini merupakan metode analisis deskriptif dengan melakukan pengukuran, pengamatan dan analisis terhadap komponen dan kinerja dari sistem Autopot Modifikasi yang akan dibuat.

Alat yang digunakan pada peneitian ini yaitu botol plastik, baki penampung, gelas ukur, mistar plastic dan Styrofoam. Alat ukur yang digunakan pada penelitian ini adalah EC meter, lux meter, $\mathrm{pH}$ meter, timbangan digital dan thermohigrometer. Bahan yang digunakan pada penelitian ini adalah air, arang sekam, humus, pupuk $\mathrm{AB}$ dan benih selada.

Adapun tahapan penelitian yang dilakukan adalah sebagai berikut:

\section{Modifikasi Autopot}

Komponen Autopot yang akan dimodifikasi yaitu pada bagian sistem fertigasi. Pada Autopot proses fertigasi dilakukan dengan menggunakan katup smartvalve yang dapat membatasi pemberian air sedangkan pada Autopot Modifikasi pemberian air diakukan dengan menggunakan lubang yang terdapat pada bagian bawah botol seperti pada Gambar 1. Lubang pada botol mempunyai fungsi yang sama dengan smartvalve.

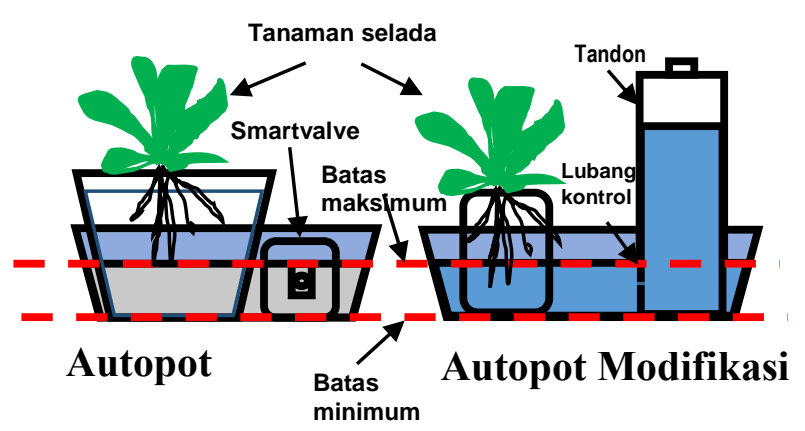

Gambar 1.Autopot dan Autopot Modifikasi

Selain itu, semua bahan yang digunakan untuk sistem Autopot Modifikasi merupakan bahan lokal sehingga mudah untuk didapatkan. Pada penelitian ini, tandon air yang digunakan berupa botol air minum 1.5 liter setinggi $32 \mathrm{~cm}$ digunakan sebagai tempat penampung larutan nutrisi yang akan dialirkan ke tanaman sedangkan untuk tempat penyimpanan botol dan pot yang digunakan yaitu bak dengan ukuran $31 \mathrm{~cm} \times 25 \mathrm{~cm}$ x $6 \mathrm{~cm}$. Botol air minum tersebut dilubangi pada bagian bawahnya dengan posisi lubang berbentuk persegi dengan ukuran $3 \mathrm{~cm} \times 1.5 \mathrm{~cm}$ dari dasar permukaan botol. Lubang ini nantinya akan berguna untuk mengalirkan larutan dari botol ke dalam wadah sekaligus sebagai kontrol tinggi muka air. Styrofoam digunakan sebagai penutup air untuk menghindari kehilangan air melalui evaporasi.

\section{Persiapan media tanam}

Media tanam yang digunakan dalam penelitian adalah kombinasi antara arang sekam dengan humus, dengan rasio komposisi media tanam sebagai berikut; Arang sekam 0\% dan Humus 100\%, arang sekam 10\% dan Humus 90\%, arang sekam 20\% dan Humus $80 \%$, arang sekam $30 \%$ dan Humus $70 \%$, arang sekam $40 \%$ dan Humus $60 \%$, arang sekam 50\% dan Humus 50\%, arang sekam $60 \%$ dan Humus $40 \%$, arang sekam $70 \%$ dan Humus $30 \%$, arang sekam $80 \%$ dan Humus $20 \%$, arang sekam $90 \%$ dan Humus $10 \%$, arang sekam $100 \%$ dan Humus $0 \%$. 
Setiap rasio campuran media dibuat pengulangan sebanyak 3 kali pengulangan sehingga jumah keseluruhan tanaman selada yang akan ditanama yaitu 33 tanaman selada.

\section{Pengamatan kondisi lingkungan}

Kondisi lingkungan yang diamati meliputi kondisi suhu udara lingkungan, kelembaban dan intensitas cahaya matahari. Pengamatan dilakukan setiap hari selama penelitian dilaksanakan.

\section{Pengamatan pertumbuhan dan hasil panen}

Pengamatan pertumbuhan dilakukan terhadap parameter tinggi tanaman dan panjang akar. Tinggi tanaman yang dihitung dari pangkal batang pada batas media tanam hingga ujung daun terpanjang (Mas'ud, 2009) yang diukur setiap 5 hari selama pengamatan berlangsung yaitu 30 hari. Panjang akar diukur dari pangkal akar hingga akar terpanjang pada saat panen bersamaan dengan pengukuran bobot panen.

\section{Analisis Efisiensi Penggunaan Air}

Efisiensi penggunaan air (WUE) dapat dihitung dengan menggunakan persamaan dibawah ini :

$$
\text { WUE }\left(\mathrm{kg} \cdot \mathrm{m}^{-3}\right)=\frac{\text { hasil produksi }}{\text { total penggunaan air }}
$$

Hasil produksi dinyatakan dalam satuan $\mathrm{kg}$, total air yang digunakan untuk menghasilkan produk dinyatakan dalam $\mathrm{m}^{3}$ serta efisiensi penggunaan air (WUE) dinyatakan dalam satuan $\mathrm{kg} / \mathrm{m}^{3}$.

\section{HASIL DAN PEMBAHASAN}

\section{Kondisi Lingkungan Penelitian}

Secara umum keadaan suhu, kelembaban udara relatif, dan intensitas sinar matahari mempengaruhi proses metabolisme yang berlangsung dalam tubuh tanaman (Ginting, 2010). Pengamatan penunjang dilakukan terhadap ketiga unsur tersebut di dalam rumah kaca Ciparanje selama 30 hari.
- Suhu Udara Rata-rata

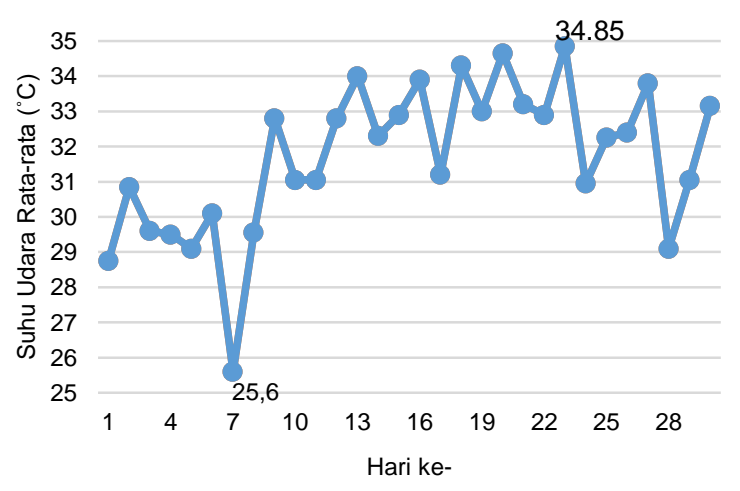

Gambar 2. Suhu Udara Rata-rata

Gambar 2. menunjukkan bahwa selama 30 hari berturut-turut, suhu rata-rata tertinggi terjadi pada hari ke 23 sebesar $34.85{ }^{\circ} \mathrm{C}$ sedangkan suhu rata-rata terendah terjadi pada hari ke 7 sebesar $25.6{ }^{\circ} \mathrm{C}$. Menurut Nisa (2014), semakin rendah suhu maka semakin tinggi nilai kelembaban udara yang berarti semakin banyak larutan nutrisi yang tertahan pada media tanam tempat tumbuhnya tanaman. Semakin tinggi suhu, semakin tinggi pula evapotranspirasi yang terjadi. Tingginya laju evapotranspirasi menyebabkan kadar air media tanam akan semakin cepat turun sehingga akibatnya terjadi pemborosan dalam pemberian larutan nutrisi.

- Kelembaban Udara

Kelembaban relatif (relative humidity) adalah perbandingan antara tekanan uap air aktual dengan tekanan uap jenuh. Hasil pengukuran kelembaban udara dapat dilihat pada Gambar 3 berikut. 


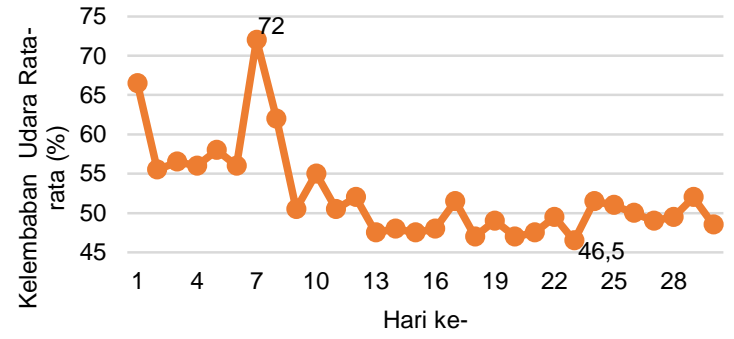

Gambar 3. Kelembaban Udara rata-rata

Menurut Rukmana (2008) dalam Hermansyah (2015) niai kelembaban udara untuk tanaman seada adalah sebesar $60 \%$, jika dibandingkan dengan nilai selada selama penelitian yang mencapai $72 \%$ kondisi tanaman selada di dalam rumah kaca tetap baik. Hal ini didukung oeh pernyataan Hermasnyah (2015) bahwa kelembaban yang dibutuhkan oleh selada merah yang terbaik berada di dalam rumah kaca.

\section{- Intensitas Cahaya Matahari}

Pengamatan terhadap intensitas cahaya matahari dilakukan pada pukul 07.00 WIB, 12.00 WIB dan 17.00 WIB di dalam rumah kaca Ciparanje. Pengukuran ini dilakukan dengan menggunakan alat ukur lux meter dengan cara menghadapkan sensor yang terdapat pada lux meter ke arah datangnya sinar matahari di dalam rumah kaca yang kemudian hasilnya akan terihat pada layar digital lux meter. Hasil pengamatan intensitas cahaya matahari dapat dilihat pada Gambar 4.

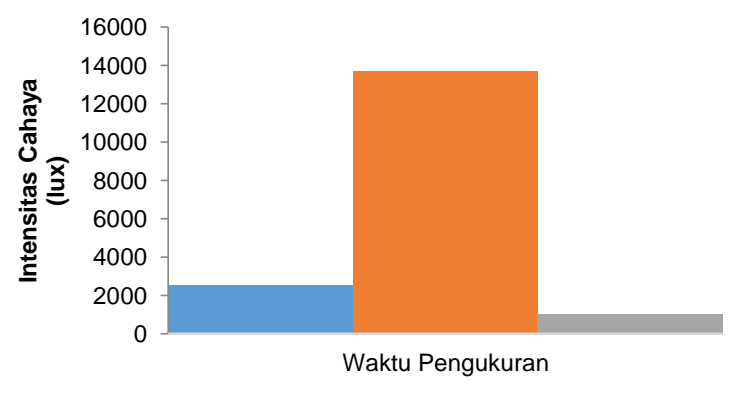

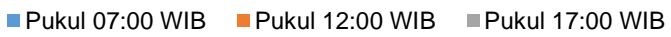

Gambar 4. Intensitas Cahaya Matahari

Kondisi rumah kaca yang digunakan dapat mempengaruhi nilai intensitas cahaya matahari. Saat melakukan penelitian kondisi atap rumah kaca terlihat kotor. Kondisi ini dapat mengakibatkan berkurangnya intensitas cahaya matahari yang masuk ke dalam rumah kaca. Menurut Harjadi (1979), tanaman yang kekurangan cahaya matahari akan mengalami etiolasi yaitu menjadi kuning serta memiliki batang yang sangat panjang dan kurus sedangkan tanaman yang diberi cukup cahaya akan membentuk warna hijau yang berhubungan dengan pembentukan klorofil, perangsang fotosintesis dan memiliki struktur yang normal.

\section{Pertumbuhan dan Hasil Tanaman}

Salah satu parameter keseragaman tumbuh yang diukur adalah tinggi tanaman. Tinggi tanaman yang dihitung dari pangkal batang pada batas media tanam hingga ujung daun terpanjang

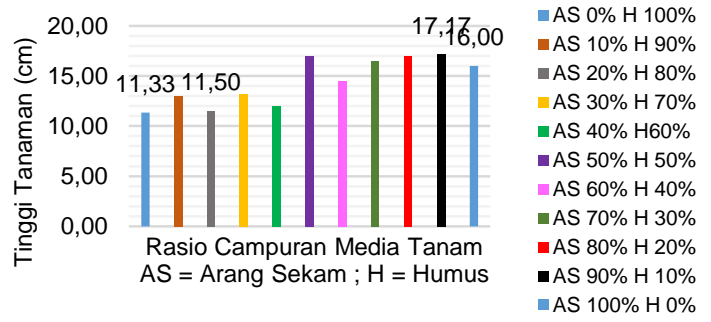

Gambar 5. Tinggi Tanaman Rata-rata Selada Merah

Pada Gambar 5 terlihat bahwa selada merah yang di tanam menggunakan media tanam dengan kandungan arang sekam yang lebih banyak dibandingkan dengan humus memiliki rata-rata tinggi tanaman lebih tinggi dibandingkan dengan selada merah yang ditanam menggunakan media tanaman dengan kandungan yang sebaliknya. Perbedaan tinggi pada tanaman selada merah ini dipengaruhi oleh faktor mikro berupa media tanam sebab tanaman selada merah yang ditanam di dalam rumah kaca diupayakan berada kondisi suhu lingkungan, kelembaban relatif serta intensitas cahaya matahari yang sama dan faktor pembedanya yaitu dari media tanam yang digunakan. Selain data tinggi tanaman, dilakukan pula analisis terhadap keseragaman tinggi.Analisis ini dilakukan untuk mengetahui 
seberapa besar tingkat keseragaman tinggi yang dihasilkan dari setiap campuran media tanam.Hasil dari perhitungan keseragaman tinggi tanaman selada merah dapat dilihat pada Gambar 6.

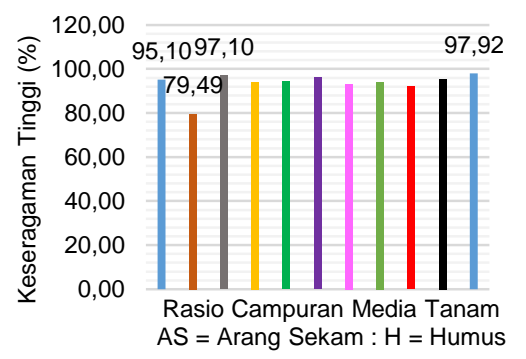

AS $0 \% \mathrm{H} 100 \%$ - AS 10\% H $90 \%$ - AS 20\% H $80 \%$ AS 30\% H 70\% -AS $40 \% \mathrm{H} 60 \%$ - AS $50 \%$ H $50 \%$ AS $60 \%$ H $40 \%$ AS $70 \% \mathrm{H} 30 \%$ - AS $80 \%$ H $20 \%$ -AS $90 \% \mathrm{H} 10 \%$ aS $100 \%$ H $0 \%$

\section{Gambar 8. Keseragaman Tinggi Tanaman Selada Merah}

Perhitungan keseragaman tumbuh tanaman selada merah diadaptasi dari perhitungan keseragaman tetesan irigasi tetes. Pada irigasi tetes, keseragaman tetesan diatas $81 \%$ dikategorikan baik.

Selain pengamatan tinggi tanaman, juga dilakukan pengamatan panjang akar sebagaimana ditunjukkan pada Gambar 7. Pengamatan panjang akar dilakukan pada saat panen yaitu 30 hari setelah melakukan pengamatan. Akar yang diukur merupakan akar tanaman yang sebelumnya terlebih dahuu dibersihkan dari media tanam dengan menggunakan air sehingga pengukuran dapat dengan mudah dilakukan.

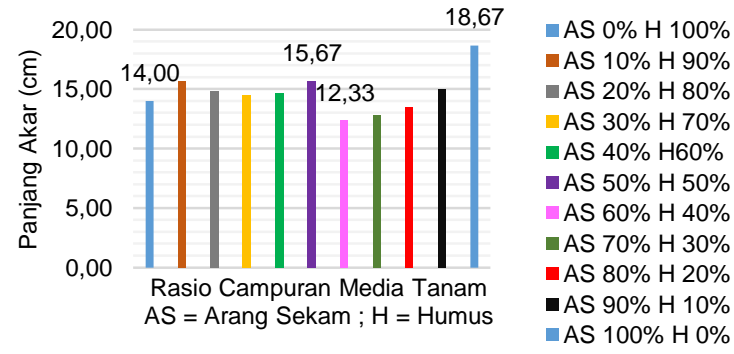

Gambar 7. Panjang Akar Rata-rata Selada Merah

Akar tanaman berfungsi menyerap air dan nutrisi dari tanah-tanah disekitar tanaman. Faktor yang berpengaruh terhadap pertumbuhan akar adalah adanya ruang poripori tanah (Kusuma, 2013). Besarnya nilai panjang akar tanaman yang terdapat pada media kontrol $100 \%$ arang sekam dipengaruhi oleh adanya kemampuan media arang sekam dalam menyerap unsur hara. Hal ini didukung oleh pernyataan Agustin dkk (2014) yang mengungkapkan bahwa media arang sekam padi merupakan media yang telah melalui proses pembakaran sehingga kadar karbon tinggi dan mudah terdekomposisi. Selain itu, arang sekam padi memiliki daya serap tinggi karena memiliki pori yang lebih besar sehingga mampu menyerap unsur hara yang ada di sekitarnya untuk disimpan dalam pori tersebut.

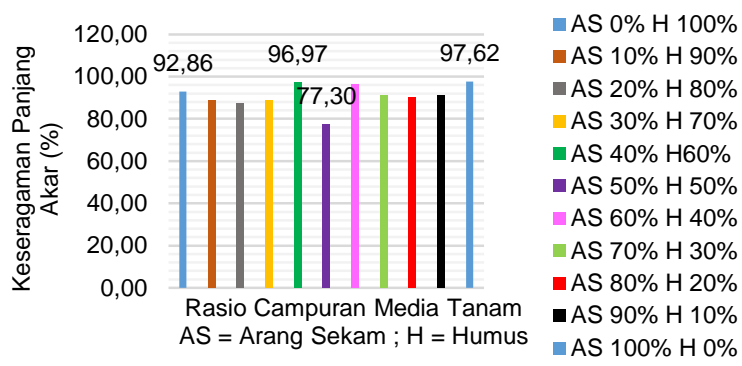

Gambar 8. Keseragaman Panjang Akar Selada Merah

Tingkat keseragaman panjang akar yang didapatkan pada pertumbuhan tanaman selada merah dikategorikan "baik" karena memiliki keseragaman lebih dari 81\% (Gambar 8). Keseragaman panjang akar yang tinggi dapat terjadi karena kondisi lingkungan, media tanam serta unsur hara yang diupayakan pada kondisi yang sama pada setiap ulangan sehingga didapatkan pertumbuhan panjang akar tanaman dengan keseragaman yang tinggi.

Pengukuran bobot tanaman selada merah dilakukan setelah 30 hari pengamatan yaitu ketika masa panen. Pengukuran bobot basah tanaman selada merah ini dilakukan dengan menimbang selada merah tanpa akar tanamannya (Gambar 9).

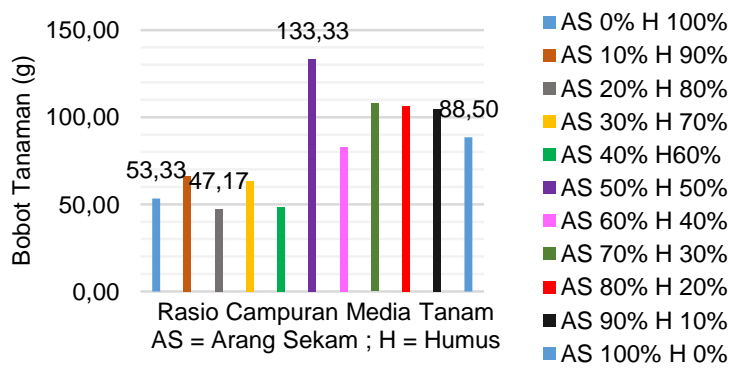


Gambar 9. Bobot Rata-rata Selada Merah

Perbedaan bobot tanaman pada setiap campuran media ini dipengaruhi oleh faktor internal pada saat pertumbuhan tanaman.Hal ini didukung oleh pernyataan Sugito (1995) dalam Wasonowati dkk (2013) yang mengatakan bahwa pertumbuhan tanaman ditunjukkan oleh pertambahan ukuran dan berat. Pertumbuhan tanaman merupakan wujud luar tanaman yang terukur juga dapat dipandang sebagai hasil kerja atau interaksi antara sifat genotipa tanaman dengan pengaruh lingkungan. Pertumbuhan tanaman dipengaruhi oleh faktor-faktor internal yang berpengaruh terhadap fisiologi hal ini termasuk dengan bobot tanaman selada merah.

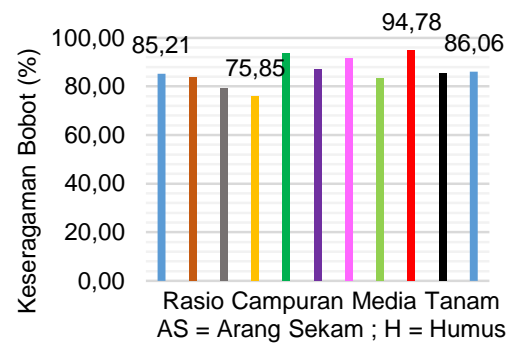

AS $0 \% \mathrm{H} 100 \%$

- AS 10\% H $90 \%$

- AS $20 \% \mathrm{H} 80 \%$

AS $30 \% \mathrm{H} 70 \%$

-AS $40 \% \mathrm{H} 60 \%$

AS $50 \%$ H $50 \%$

AS $60 \%$ H $40 \%$

AS $70 \% \mathrm{H} 30 \%$

AS $80 \%$ H $20 \%$

-AS $90 \%$ H $10 \%$

AS $100 \% \mathrm{H} 0 \%$

Gambar 10. Keseragaman Bobot Selada Merah

Hasil keseragaman tumbuh mulai dari keseragaman tinggi tanaman, keseragaman panjang akar serta keseragaman bobot menunjukkan bahwa tanaman yang ditanaman pada sistem Autopot Modifikasi dapat tumbuh secara optimal dengan baik sebagaimana ditunjukkan pada Gambar 10. Hasil keseragaman yang mampu mencapai $90 \%$ pada setiap kriteria keseragaman terbilang mempunyai kategori baik untuk pertumbuhan tanaman selada merah yang dikembangkan pada sistem Autopot Modifikasi.

\section{Efisiensi Penggunaan Air}

Sistem pengairan yang terdapat pada Autopot Modifikasi merupakan sistem irigasi bawah permukaan. Air yang mengalir dari botol penampung dengan bantuan gaya gravitasi mengairi baki dan tanaman dengan kondisi baki yang tertutup untuk menghindari evaporasi oleh cahaya matahari. Kondisi air pada baki akan terus berada pada batas maksimum karena pengurangan air yang dihitung terbatas pada pengurangan air dalam botol, begitupun dengan pengisian air dilakukan ketika air yang terdapat botol sudah mulai berkurang.

Hasil penelitian menunjukkan bahwa efisiensi penggunaan air rata-rata pada Autopot Modifikasi dengan pemberian air dilakukan pada hari ke 10, hari ke 20 dan ke 25 setelah tanam mencapai $51.43 \mathrm{~kg} / \mathrm{m}^{3}-88.72 \mathrm{~kg} / \mathrm{m}^{3}$. Tingginya efisiensi ini karena penggunaan air yang rendah namun hasil produksi yang tinggi sehingga nilai efisiensi tinggi.

Hal ini juga didukung oleh pernyataan Haryati dkk (2010) bahwa semakin tinggi hasil tanaman, semakin tinggi pula nilai efisiensi penggunaan airnya.Semakin tinggi penggunaan air, semakin rendah efisiensinya.Selain itu, menurut Ayars et al (1999), efisiensi penggunaan air oleh tanaman disamping dipengaruhi oleh jenis teknik irigasi yang digunakan, juga dipengaruhi oleh jenis tanaman yang diusahakan dan kondisi lokal yang mencakup iklim dan jenis tanah.

\section{Pengaruh Media Tanam}

Pada penelitian ini media tanam yang digunakan merupakan campuran antara arang sekam dan humus. Kedua media tanam ini merupakan media tanam yang mudah untuk didapatkan dibandingkan dengan media tanam yang lain. Terdapat 9 macam rasio campuran media antara arang sekam dan humus.Banyaknya rasio yang digunakan ini bertujuan untuk mengetahui kemampuan setiap rasio campuran media dalam budidaya tanaman selada merah.

Hasil dari penelitian yang ditampilkan pada Gambar 5 hingga Gambar 10 menunjukkan bahwa, terdapat perbedaan hasil di setiap kriteria pengamatan pada setiap rasio media tanam. Rasio media tanam yang mempunyai hasil yang paling baik diantara rasio yang lain adalah rasio campuran $50 \%$ arang sekam dan $50 \%$ humus. Pemilihan rasio ini berdasarkan dari hasil data penelitian berupa kriteria tinggi tanaman, panjang akar, bobot tanaman, indeks luas daun serta efisiensi 
penggunaan air yang menunjukkan bahwa campuran tersebut memiliki hasil yang paling baik diantara yang lain.

Rasio media tanam yang terbaik pada Autopot Modifikasi juga sesuai dengan rasio media tanaman yang dianjurkan pada sistem Autopot.Sistem Autopot menganjurkan untuk menggunakan media perlite dan vermikulit dengan rasio 50:50.Namun pada sistem Autopot Modifikasi media tanam yang digunakan menggunakan media arang sekam dan humus karena harganya yang lebih terjangkau dan mudah didapatkan.

Komposisi arang sekam dengan humus sebesar 50:50 mengakibatkan media memiliki lebih banyak pori-pori dan tidak padat sehingga akar tanaman dapat melakukan respirasi karena adanya udara pada pori-pori media.Hal ini didukung oleh pernyataan Harjadi (1988) yang menyatakan bahwa jumlah serapan unsur hara untuk tanaman sangat ditentukan oleh keseimbangan air dan udara di dalam media tanam. Bila udara dan air seimbang di dalam media tanam, maka akar tanaman akan menyerap unsur hara dalam jumlah yang cukup sehingga pertumbuhan tanaman meningkat.

Humus dan arang sekam sama-sama memiliki kemampuan menahan air yang baik sehingga air yang terikat lebih banyak pada media. Saat kedua media ini dicampurkan air yang terserap oeh humus akan ditahan oleh kedua media tanam yang nantinya air tersebut akan dilepaskan saat dibutuhkan. Walaupun air yang terikat pada media akan lebih banyak hal tersebut tidak akan membuat media menjadi kelebihan air karena adanya pori-pori yang dihasilkan arang sekam sehingga air yang berlebih dapat diloloskan dengan proses drainase.

Selain itu pula, adanya campuran arang sekam dan humus dapat mempermudah pertumbuhan akar. Penambahan arang sekam dapat membuat campuran media memiliki ruang pori yang memudahkan akar untuk tumbuh memanjang serta memudahkan dalam mendapatkan unsur hara. Hal ini juga disebabkan oleh pencampuran media humus dan arang sekam membuat media tanam mudah ditembus akar karena strukturnya tidak padat.

\section{SIMPULAN}

Kesimpulan yang dapat diambil dari penelitian ini adalah bahwa campuran media tanam antara arang sekam dan humus dengan rasio komposisi $50 \%$ arang sekam dan $50 \%$ humus menunjukkan hasil pertumbuhan tanaman yang lebih baik dibandingkan dengan rasio yang lain dengan tingkat keseragaman tumbuh rata-rata sebesar $89.97 \%$ untuk semua parameter. Kinerja Autopot Modifikasi ditunjukkan dengan efisensi penggunaan air sebesar $51.43 \mathrm{~kg} / \mathrm{m}^{3}-88.72 \mathrm{~kg} / \mathrm{m}^{3}$, efisiensi ini tergolong tinggi karena produksi tanaman yang dihasilkan tinggi dengan penggunaan air yang rendah.

\section{Daftar Pustaka}

Agustin, D. A., Riniarti dan Duryat.2014. Pemanfaatan Limbah Gergaji dan Arang Sekam Sebagai Media Sepih untuk Cempaka Kuning (Michelia champaka).Jurnal Sylva Lestari Volume 2 No 3 Halaman 49-58.

Ayars, J. E., C.J. Phene, R. B. Hutmacher, K. R. Davis, R. A.Schoneman, S. S.Vail and R. M. Mead. 1999. Subsurface drip irrigation of row crops : a review of 15 years research at the Water Management Research Laboratory. Agric. Water Manage 42 (1) 1- 27. Elsevier B. V.

Harjadi, S. S. 1988. Pengantar Argonomi. PT. Gramedia: Jakarta.

Haryanto, E., T. Suhartini dan E. Rahayu. 2003. Sawi dan Selada. Penebar Swadaya: Jakarta

Haryati, U., A. Abdurachman dan K. Subagyono. 2010. Efisiensi Penggunaan Air Berbagai Teknik Irigasi untuk Pertanaman di Lahan Kering pada Typic Kanhapludult Lampung. Terdapat pada: balittanah.litbang.deptan.go.id. Diakses pada tanggal 15 Mei 2009 pukul 22.18 WIB 
Hermansyah, R. 2015. Kajian Data Suhu Udara, Kelembaban Relatif Udara dan Intensitas Cahaya Matahari Terhadap Perkembangan Tanaman Selada Merah (Lactuva sativa L) di Luar dan di Dalam Rumah Kaca.Skripsi.. Fakultas Teknologi Industri Pertanian. Universitas Padjadjaran.

Ginting, C. 2010. Analisis Pertumbuhan Selada (Lactuca sativa) Dibudidayakan Secara Hidroponik Pada Musim Kemarau dan Penghujan.Agriplus Vol. 20 No 1 Januari 2010 ISSN 0854-0128.James, L. G. 1988.Principle of Farm Irrigation System Design. John Wiley and Sons Inc: Canada.

Junior, J. Benton Jones. 2005. Hydroponics: A Partical Guide for the Soilless Grower Second Edition. CRC Press: New York.

Kusuma, D. A. 2013. Indeks Mitosis Ujung Akar Kecambah dan Anatomi Batang Serta Daun Tanaman Tomat (Lycopersicum escuentum) Dibawah Pemaparan Medan Magnet 0.2 $m T$.Skripsi.Fakutas Ilmu Matematika dan Pengetahuan. Universitas Lampung: Bandar Lampung.
Mas'ud, H. 2009. Sistem Hidroponik dengan Nutrisi dan Media Tanam Berbeda terhadap Pertumbuhan dan Hasil Selada.Media Penelitian dan Pengembangan Sulawesi Tengah 2 (2).

Nisa, S. N. 2014. Uji Komparasi Media Tanam Arang Sekam dan Cocopeat pada Metode Hidroponik Substrat Tanaman Selada Lollo Rossa.Skripsi. Fakultas Teknologi Industri Pertanian. Universitas Padjadjaran.

Nurpilihan Bafdal, Sophia Dwiratna and Dwi Rustam Kendarto, 2017. Impact of Water Use on Paprika (Capsicum annum) by Using Fertigation and Autopot System Combined with Numerous Growing Media. Asian Journal of Plant Sciences, 16: 149-159

Rukmana, R. 1994. Bertanam Selada dan Andewi. Kanisius: Yogyakarta.

Wasonowati, C., S. Suryawati dan A. Rahmawati. 2013. Respon Dua Varietas Tanaman Selada (Lactuca sativa L) terhadap Macam Nutrisi pada Sistem Hidroponik.Agrovigor Volume 6 No 1. 